\title{
THE BOTANICAL SIDE OF A ZOOLOGICAL PARK IN COIMBATORE, INDIA
}

\author{
N.V.K.Ashraf \\ Assistant Director, Coimbatore ZoologicalPark and Conservation Centre, Anaikatty, Coimbatore, Tamil Nadu 641108, India
}

\begin{abstract}
Recreating different forest types in a zoo demands total commitment and appropriate professional expertise. The Coimbatore Zoological Park has been striving for the past four years (1994-98) to simulate or recreate eight different forest types of the Nilgiris at the site. Work on three of these eight vegetation zones have already begun. The experience gained during the last 4 years show that it is possible to recreate at least seven of these vegetation types using the same species found in the wild. Seedlings are either purchased from outside or propagated at the zoo itself. Many of the tropical wet evergreen species have been propagated, planted and firmly established at the zoo. Every botanic activity, including the outcome of every propagation and planting attempt, is recorded and analyzed through a computer software named ENTADA. Immediate future plans include the installation of a pair of rain guns for irrigating the rainforest zone, a green house for acclimatizing young rainforest seedlings to local conditions and initiation of Botanic Education Programmes for students.
\end{abstract}

\section{Introduction}

Historically, Botanical Gardens have been designated for plants and Zoological Parks for animals. A Botanical Garden can exist without animals but no Zoological Park is complete without plants. Plants have been used in zoos for (i) providing shade inside animal enclosures, (ii) as hedge plants or shady trees along pathways and (iii) as decorative backdrops behind exhibits. Zoos in India still employ plants mainly for the first two purposes mentioned. Any attempt to recreate or simulate wilderness has been traditionally restricted to exhibits (Ashraf, 1996).

Though plants and animals are interdependent for every aspect of their biological requirements, it often becomes difficult to exhibit an animal with its associated species of plants in an exhibit. The victim is invariably the plant, suffering at the hands of grazers, browsers and folivorous primates. Integrating an animal with its associated plants is therefore a difficult exercise, demanding professional expertise. Zoos in the west have fulltime faculty solely for looking after their horticultural requirements. Zoo horticulture, still a new profession, now has a major role to play in replicating a wide range of bioclimatic zones like rainforest, temperate forest, grasslands and deserts. Animal exhibits are created within these zones, so that the visitors while strolling through the vegetation, can get the feeling of sharing the same environment of the animal. This concept of "landscape immersion" is now gaining popularity in zoological parks worldwide (Coe, 1996; Polakowski, 1987).

The role of plants at the Coimbatore Zoological Park (CZP) took a major turn in 1994 when the CZP Society decided to develop the zoo as a BioPark of the Nilgiri Biosphere Reserve (NBR). Consequently, the spectrum of plant species selection has been narrowed down to 'native Western Ghats species' from the earlier idea of 'native Indian species'.

Zoos in temperate countries have limitations while attempting to recreate a tropical forest in an open environment. They either recreate them indoors or use native plants, which resemble the ones found in the vegetation type to be replicated. The Ford African Rainforest at Zoo Atlanta is a fine example of simulating a tropical forest outdoors using native temperate forest species (Jackson, 1996). The Coimbatore Zoological Park has gone a step further by employing the exact species of plants while recreating the different forest types. There are advantages as well as disadvantages in restricting the species choice. Being located in the Nilgiri Biosphere Reserve (Fig:1), the zoo is ideally placed to obtain the species list of different forest types that are meant to be recreated. The disadvantages include (a) difficulty in procuring the forest plants that are not normally available in commercial nurseries and (b) in establishing plants of humid and high altitude rainforests in a rainshadow environment.

This paper describes the objective of recreating forest types, developments that have taken place in the botanical field at the zoo and the future plans for conservation of plant species.

\section{CZP: An interpretation Centre for the NBR}

Newer zoos have an overall theme of animal collection and exhibition. Since the emphasis is on the conservation of native animals, many zoos have begun to concentrate on animals of their respective biogeographic region. The Arizona Sonerat Museum and the Northwest Trek, both in the US, are probably the two best examples of this.

The Coimbatore Zoological Park site, situated on the eastern 


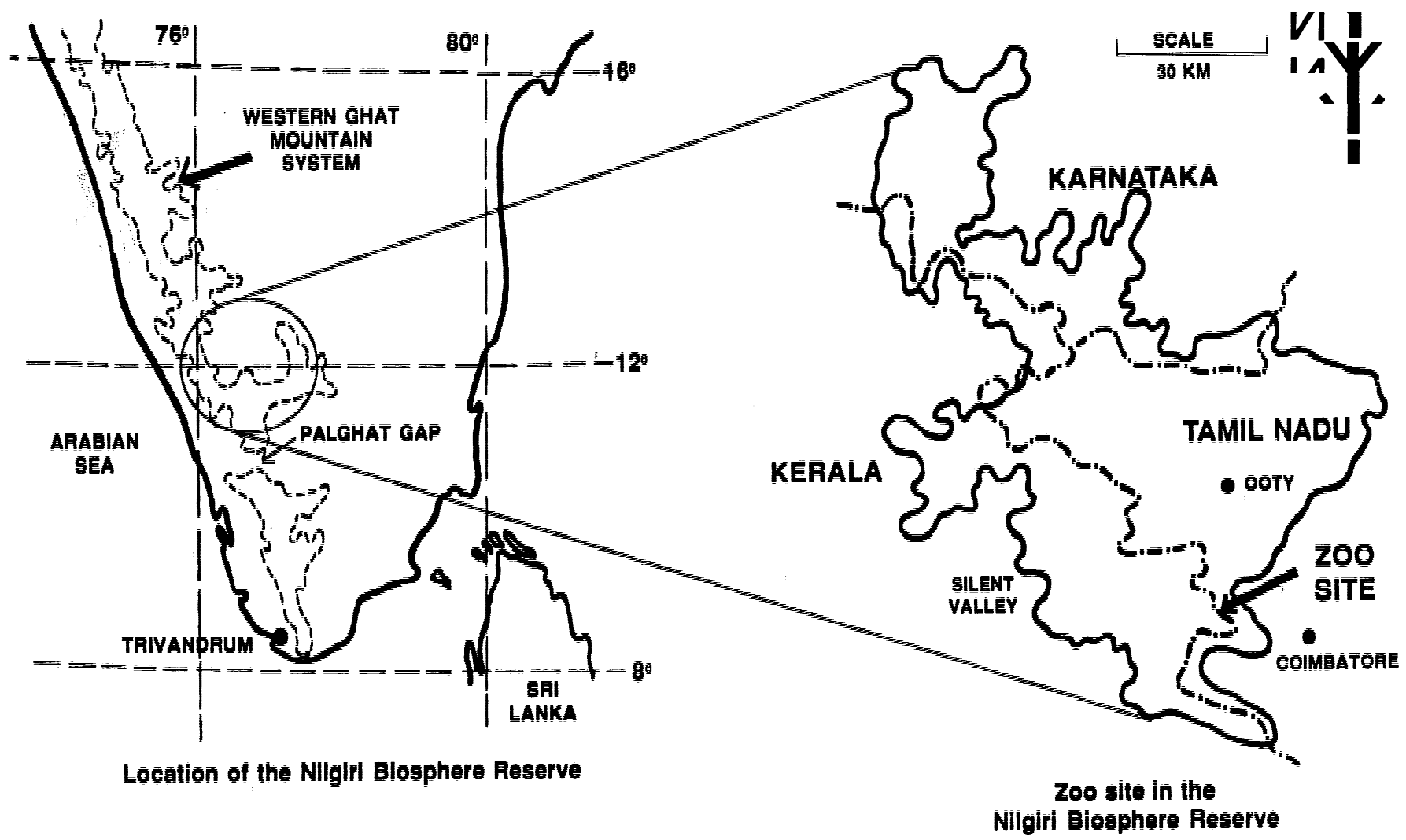

Figure 1. Coimbatore Zoological Park in the Nilgiri Biosphere Reserve

slopes of the Nilgiri hills, has appropriately chosen the Nilgiri Biosphere Reserve (NBR), as the 'theme'. The Western Ghats is one among the Mittermeier and Myer's 24 'hot-spots' of plant diversity in the world. Rich in endemic species, the NBR, is perhaps the most widely known mountain part of the Western Ghats. The zoo will be a replica of this Biosphere Reserve, focusing on the conservation and education of its flora and fauna, thus functioning as an interpretation centre for the NBR (Walker et al., 1999).

The project site

The Coimbatore Zoological Park site lies in the rainshadow part of the NBR at an altitude of about $600 \mathrm{~m}$. in Thuvaipathy Village of Anaikatty $\left(11^{0} 6^{\prime} \mathrm{N}, 76^{\circ} 45^{\prime} \mathrm{E}\right)$, about $30 \mathrm{~km}$. from Coimbatore. The proposed 250 acre site constitutes a part of the large two square kilometre catchment area. The site lies juxtaposed to the Perinaickenpalayam Reserve Forest on the east. Two hill slopes, northern and southern, also form a part of the zoo. The hills elevate to 80 to $120 \mathrm{~m}$. from the valleys (Fig 2).

The vegetation type in the adjoining Reserve Forest could be considered as an intermix of Thorn and Dry Deciduous forest species, which is typical of the forest in Nilgiri Eastern Slopes (Table 1). Barring two coconut groves of about 10 acres, the site is a barren hilly terrain that has been partly terraced for cultivating
Table 1. Major species of plants (trees and shrubs) in the Reserve Forest adjoining zoo land.

\begin{tabular}{ll}
\hline & Large trees \\
Acacia leucophloea & Dendrocalamus strictus \\
Ailanthus excelsa & Diospyros montana \\
Albizia amara & Gyrocarpus asiaticus \\
Bauhinia racemosa & Phyllanthus polyphyllus \\
Catunaregam spinosa & Pleiospermium alatum \\
Chloroxylon swietenia & Pongamia pinnata \\
Commiphora caudata & Pterocarpus marsupium \\
Cordia obliqua & Schleichera oleosa \\
Dalbergia latifolia & Terminalia arjuna \\
Dalbergia paniculata & Ziziphus mauritiana \\
& \\
& \\
Agave americana & Others (shrubs etc.) \\
Atalantia monophilla & Glycosmis pentaphylla \\
Capparis roxburghii & Lantana camara \\
Cycas circinalis & Mundulea sericea \\
Euphorbia antiquorum & Ziziphus oenoplia \\
\hline
\end{tabular}




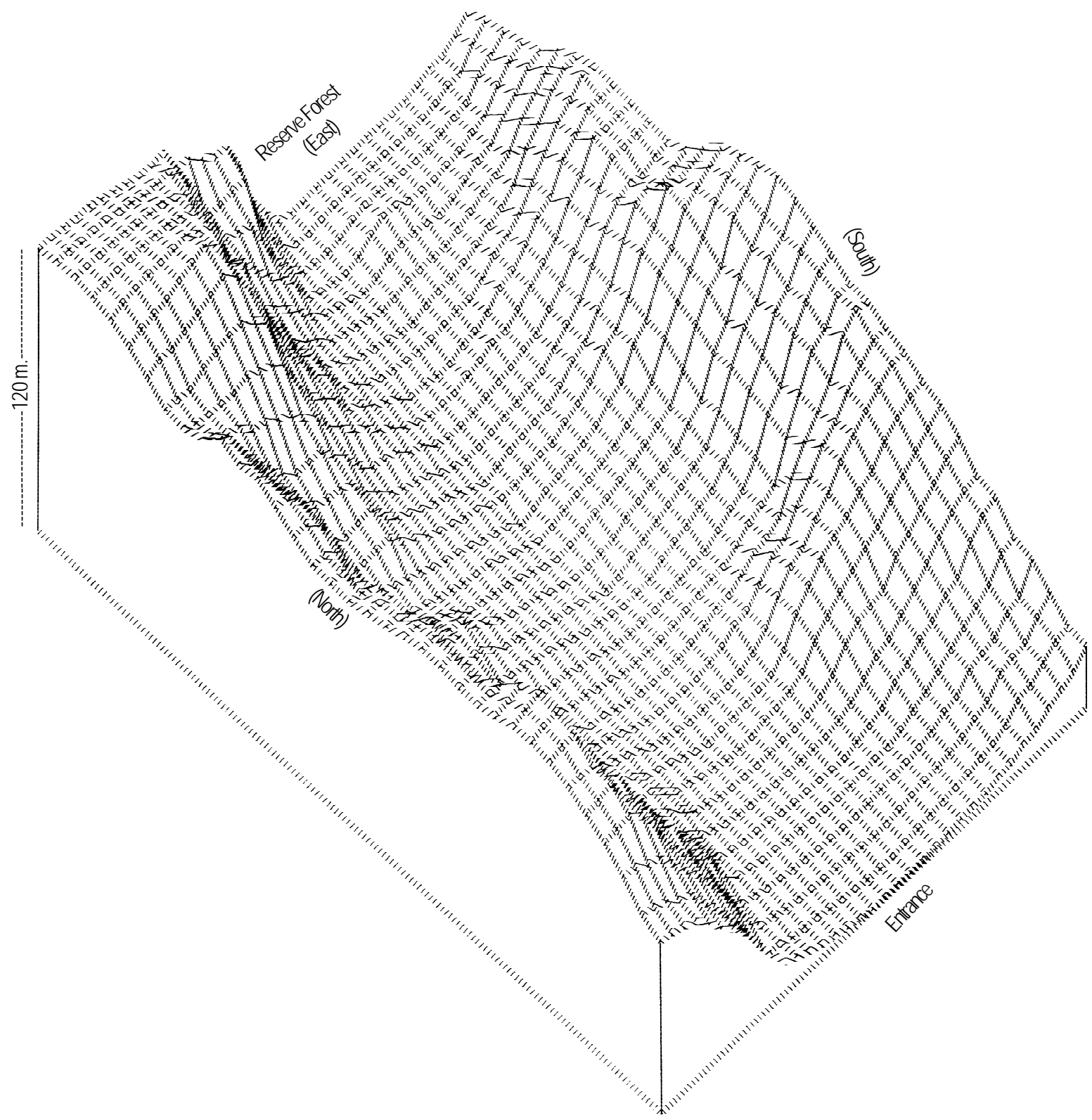

Figure 2. A three dimensional profile of the zoological park site

marginal crops.

The ambient temperature at the site varies from $22^{\circ} \mathrm{C}$ to $35^{\circ} \mathrm{C}$ during the day. The site receives an annual rainfall of about $1,200 \mathrm{~mm}$., much of which is received during the northeast monsoon (October to January). Day time humidity levels vary from 40 to 55 per cent during the dry season (January to April) and from 60 to 100 per cent during the monsoons (August to November). The ground water situation is satisfactory and the site is well served by wells and borewells. The area is influenced by strong winds during June to September.

\section{Vegetation zones}

Unlike the taxonomic criterion followed in most botanic gardens for organizing their collection (as palms, figs, ferns, orchids, conifers, herbal garden etc.), the organization concept at CZP is ecological or bioclimatic. The entire area has been arbitrarily divided into eight thematic vegetation zones (Fig. 3). The largest of these zones is the Rainshadow Forest Zone (with an extent of about 90 acres) and the smallest is the Semi-Evergreen Zone (about 6 acres). When more than two or three vegetation associations exist within a forest type, the zone is further divided into Vegetation Belts. The Moist Deciduous Zone, for instance, has been divided into three belts: Moist Teak Forest, Bamboo 


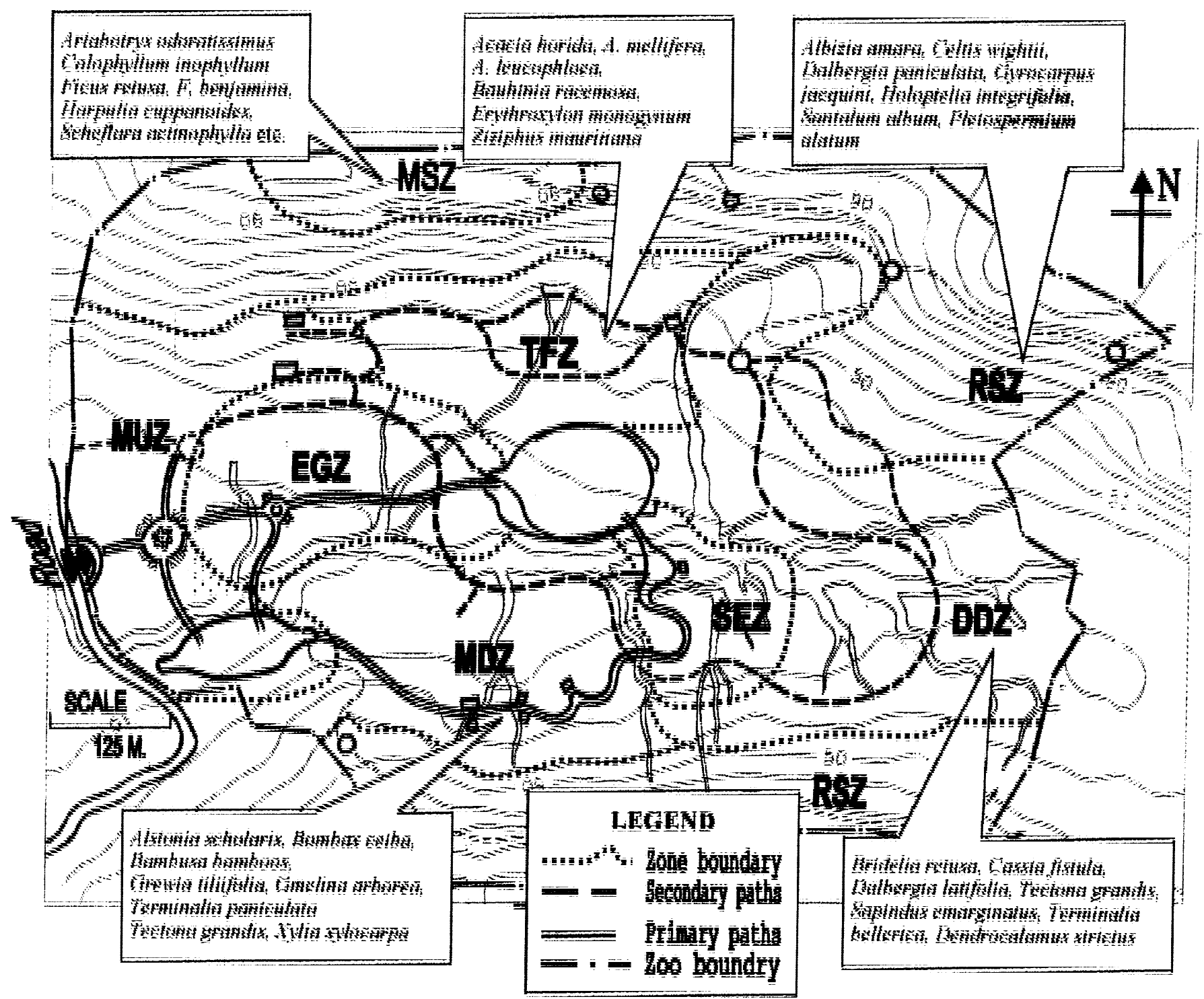

Figure 3. Thematic vegetation zones at CZP

DDZ: Dry deciduous Zone; EGZ: Evergreen Zone; MDZ: Moist Deciduous Zone; MSZ: Montane Shola Zone MUZ: Multiple Use Zone ; RSZ: Rain Shadow Zone; SEZ: Semi-Evergreen Zone; TFZ: Thorn Forest Zone

Brakes and Mixed Deciduous Forest. For managerial reasons, each belt has been further subdivided into Units, each comprising several Blocks. The size of a Block varies from 1000 to 4000 sq.m. The Blocks have an Inventory Box containing the A-to-Z list of plants planted in it.

\section{Current activities}

The focus now is on the development of Evergreen, Moist Deciduous and Multiple Use Zones. The Zoo has been collecting and propagating forest plants since 1991 in order to plant them in the designated vegetation zones during rainy season.

\section{Collection}

Since the focus is on plants of the Nilgiris, plant collection efforts have been restricted to non-governmental and governmental nurseries that deal with native Western Ghats species. Seed collection trips are organized every year to different forest areas, coinciding with the fruiting season during summer. Table 2 shows the key species of rainforest seeds collected in 1997 and 1998.

Plants are also purchased from institutions like KFRI, Trissur, TBGRI, Thiruvananthapuram, PHCC, Dindigul and the Karnataka Forest Department. A record number of 95 species of plants were purchased in 1997. Some of the Western Ghat endemics collected so far include Calamus pseudotenuis, Artocarpus 
Table 2. Seeds of key rainforest species collected during 1997 and 1998

\begin{tabular}{ll}
\hline ... in 1997 & ... in 1998 \\
Breynia vitis-idaea & Arenga wightii \\
Celtis philippensis & Baccaurea courtallensis \\
Cinnamomum malabatrum & Canarium strictum \\
Diospyros bourdillonii & Cullenia exarillata \\
Entada rheedii & Dialium tranvancoricum \\
Garcinia spp. & Dysoxylum malabaricum \\
Harpulia arborea & Jasminum angustifolium \\
Hydnocarpus alpina & Leea indica \\
Hydnocarpus pentandra & Myristica dactyloides \\
Knema attenuata & Polyalthia coffeoides \\
Syzygium mundagam & Semecarpus travancorica \\
Vateria indica & Sterculia foetida \\
\hline
\end{tabular}

hirsutus, A. heterophyllus, Vateria indica, Polyalthia fragrance, Myristica malabarica, Kingiodendron pinnatum, Canarium strictum and Palaquium ellipticum.

\section{Propagation}

Many species of rare forest plants have been successfully propagated at the Zoo. Plant propagation attempts were intensified during the last two years in order to increase species diversity. As a result, the number of seedlings procured from outside has steadily decreased over the years in response to the increase in the number of propagations. Valuable information on the propagation success of many rainforest plants has been obtained from germination of seeds and rooting of cuttings. For every species tried, information on 'percent emergence' and 'percent survival' are recorded. Some of the important species propagated in 1997 are Bombax ceiba, Harpulia arborea, Pterygota alata, Vateria indica, Leea indica, Arenga wightii, Garcinia talbotii, Elaeocarpus tuberculatus, Ensete superbum, Diospyros melanoxylon, Ficus microcarpa, Ficus hispida, Ficus heterophylla, Ficus tsjahela, Knema attenuata, Alseodaphne semecarpifolia, Dillenia pentagyna and Myristica dactyloides. However, attempts to propagate and establish some of the Montane Shola Forest species in the nursery was met with little success. Some of the species tried include $E$. recurvatus, Rubus wightii, Syzygium densiflorum, Fuschia hortensis and Michelia nilagirica.

\section{Planting}

Three of the eight vegetation zones have been planted with nearly 7,700 seedlings of 230 species of trees, shrubs, palms, canes and bamboos, covering an extent of about 20 acres. The planting species diversity has increased steadily over the years. More than 30,000 seedlings of 230 species are being currently maintained in the nursery for planting in the designated zones. As far as possible, planting has been carried out in proportion to the numbers found in the wild.
The Rainforest Zone alone has 4,000 plants of 136 species. Most of these seedlings are now more than four years old and more species are being added every year. The performance of these trees is being monitored every two years by recording their height and girth at breast height. Except for a few species like Garcinia morella, Palaquium ellipticum, Mesua ferrea, Vateria indica and Cinnamomum verum, others have shown signs of getting acclimatized to the local rainshadow environment. Species like Persea macrantha, Acrocarpus fraxinifolius, Lagerstroemia microcarpa, Bischofia javanica, Hydnocarpus pentandra, Artocarpus hirsutus, Dysoxylum binectariferum, Garcinia gummi-gutta, Mimusops elengi, Ficus tsjahela, Ficus beddomei, Hopea ponga, Elaeocarpus tuberculatus and Vitex altissima have been successfully established at the site.

Plants in the Moist Deciduous Zone are nearly three years old. Some of the 64 species planted in the Moist Teak Forest Belt of this zone include Tectona grandis, Grewia tiliifolia, Dillenia pentagyna, Xylia xylocarpa, Terminalia bellerica, Terminalia alata, Gmelina arborea, Bambusa bamboos, Haldina cordifolia, Spondias pinnata, Radermachera xylocarpa, Emblica officinalis, Ficus racemosa, Caryota urens and Bridelia retusa

Planting in the Multiple Use Zone began in 1995. More than 1,500 plants belonging to 135 species have been planted in three different belts by 1998 . This zone largely contains exotic species like as Artocarpus communis, Aleurites fordii, Khaya senegalensis, Swietenia mahagony, Polyalthia longifolia, Cananga odorata, Swietenia macrophylla and Pterospermum acerifolium.

\section{Research}

Research is an integral part of CZP's development programmes. Botanical research is no exception. The centre realizes the potential of the voluminous amount of data generated from the routine propagation and planting activities.

\section{Germination studies}

The centre has so far propagated 17 species of rainforest endemics, many of which have probably been propagated for the first time in a zoo situation. Some of the endemic species propagated at the zoo include Artocarpus hirsutus, Baccaurea courtallensis, Dysoxylum malabaricum, Palaquium ellipticum, Canarium strictum, Vateria indica, Hydnocarpus pentandra and Cullenia exarillata.

Records are maintained on all parameters of the germination process. Seeds are subjected to various methods of treatment for studying their germination success. Sometimes, the germination success of seeds collected from wild civet scats and hornbill droppings are investigated and compared with that of untreated seeds. 


\section{Pests and diseases}

The centre has launched a research project on the pests and diseases of forest plantations in collaboration with the Bharathiar University, Coimbatore. The project, completed in 1998, investigated into the prevalence and intensity of pests and diseases of plants at the Zoo. The research findings are expected to help the Zoo in formulating appropriate pest and disease control measures.

\section{Software for botanical management}

The Centre has developed a computer software for managing the enormous quantity of data generated on account of the dayto-day botanic activities. Named after India's largest podbearing climber Entada rheedii, the program ENTADA has now become an important tool for managing plant collections at the Zoo.

ENTADA is built around six modules: Collection, Propagation, Planting, Mortality, Disposal and Museum Specimens. Each module has a standard menu driven option with advanced features to offer flexibility and user friendly environment. The programme takes into account of all living plants (both planted and unplanted) and keeps track of the total quantity of every species, whether collected, propagated or planted.

The output menu can generate six types of reports: Taxon Report, Module Summaries, Rigid Report, Flexible Report, Trend and Current Stock. The software is now being subjected to rigorous tests for programming errors. Once this is done, CZP is planning to market this software for the benefit of botanists, horticulturists and plantation officers working in other organizations.

\section{Future plans}

\section{Botanic education}

The zoo is looking forward to launch a project on botanic education with the help of funds from outside. The project envisions to expose students to botanical diversity in rainforests; and provide them a hands-on experience in plant propagation methods. The centre is also planning to prepare a booklet on interesting unconventional fruit yielding plants of Western Ghats.

\section{Collection plan}

Nearly 84 per cent of the plants and 43 per cent of the species planted in the Evergreen Zone so far have been trees. The remaining is composed of shrubs, palms, canes and climbers. Once the canopy gaps are filled with more shrubs, the next step would be to enrich the rainforest zone with ferns and orchids.

\section{Infrastructure}

While the propagation of rainforest species has been by and large successful, most of the seedlings fail to survive for even one year owing to alien climatic conditions. The Zoo plans to build a green house to accommodate the newly emerged rainforest seedlings and maintain them ex situ for two to three years before they could be considered hardy enough to withstand the local climatic conditions.

\section{Planting}

Only three of the proposed eight vegetation zones have been covered, extending over an area of about 25 acres, which is only 10 per cent of the total extent designated for the all the zones put together. The remaining five zones are expected to be covered by 2010 . Planting in the thorn forest zone will begin during this monsoon. The Zoo management is also planning to install two rain-guns to irrigate plants of the rainforest zone.

\section{An Ecological Park in the making ...}

Converting a barren One sq. km. of barren catchment zone into a mosaic of varying tropical forest types is indeed a mammoth task. The task becomes all the more difficult when the plan is to use the respective plant species for various forest types and plant associations. The Montane Shola Forest Zone alone will have to be recreated using local plants. Nevertheless, the advantage of choosing a native bioclimatic zonation as the organization theme is very obvious. The Zoo is in a position to procure the seeds or cuttings of rare species and propagate them at the Zoo itself. The process has only just begun and will take another 15-20 years to establish vegetation cover.

Soon visitors can see a 'rainforest' in the core area, a 'shola forest' on the undulating hill-tops, a 'moist deciduous forest' along the southern slopes, a 'thorn forest' along the foothills of the northern slopes, a 'dry deciduous forest' close to the reserve forest, a 'rainshadow forest' along the hill topes and a 'multiple use zone' along the western part of the park. With exhibits of various animal species being distributed across these vegetation zones, the Coimbatore Zoological Park is envisioned to become an Ecological Park, with collections of interest to both zoologists and botanists.

\section{References}

Ashraf, N.V.K. (1996). Lessons from Indian Zoos: A report on the brief tour of selected Indian zoos. Technical Report 4. Coimbatore Zoological Park and Conservation Centre, Coimbatore, India.

Coe, J.C. (1996). What is the message? Education through exhibit design. In: Wild Mammals in Captivity. Editors: Kleiman D.G. et al). University of Chicago Press. Chicago and London. Pp 167-174.

Jackson, D.W. (1996). Horticultural philosophies in Zoo Exhibit Design. In: Wild Mammals in Captivity. Editors: Kleiman D.G. et al). University of Chicago Press. Chicago and London. Pp 175-177

Polakowski, K.J. (1987). Zoo Design: The Reality of Wild Illusions. The University of Michigan. School of Natural Resources. U.S.A.

Walker, S., N.V.K. Ashraf., B. Rathinasabapathy., B.K. Gupta and Adit Pal. (1999). The Nilgiri Biosphere Conservation Park: Biodiversity Conservation for the 21st Century. Proc. of the 5th Int. Zoo Design. (Eds.) A.B. Plowmann and P.M.C. Stevens. Whitley Wildlife Conservation Trust 